\title{
Improving the Quality of "The Internet of Things" Instruction in Technology Management, Cybersecurity, and Computer Science
}

\author{
Darrell Norman Burrell, Florida Institute of Technology, Melbourne, USA \\ Ashley Courtney-Dattola, Capella University, Minneapolis, USA \\ Sharon L. Burton, Florida Institute of Technology, Melbourne, USA \\ Calvin Nobles, University of Maryland Global Campus, Largo, USA \\ Delores Springs, Regent University, Virginia Beach, USA \\ Maurice E. Dawson, Illinois Institute of Technology, Chicago, USA
}

\begin{abstract}
Many universities require end of course evaluations for all courses taught as tool for academic accreditation purposes. The reality is that often many academic departments either do not do anything or have no idea what to do when evaluations continue to be poor. As a result, students have fought back against this process to create their own on-line rating program, Rate My Professor.com, which allows students to give other students insights into who is a quality professor and who is not. This paper explores this use of mock teaching simulations, which are also called Micro-teaching approaches, as a quality management tool to improve the way students are taught in Technology Management, Cybersecurity, and Computer Science degree and certificate programs.
\end{abstract}

\section{KEYWORDS}

Computer Science Instruction, Cybersecurity Faculty, Faculty Development, Technology Management

\section{INTRODUCTION}

Recent growth and changes in the areas of Technology Management and Cybersecurity have occurred so rapidly that educators have not had the time to assess whether they are teaching this material in a manner that will promote student success in the classroom and encourage students to continue to pursue degrees and careers in the field (Burrell at el, 2015). Within computer science, the sub-field of cybersecurity has seen tremendous growth over the past two decades (Burrell \& Nobles, 2018). With the growth of the internet, the proliferation of network-capable computing devices, and the vast quantity of data being stored in digital formats, the need for professionals capable of securing communication channels and information storage has become a critical task for government entities, businesses, and individuals (Burrell \& Nobles, 2018). This growth has occurred so rapidly that the academic pipeline has not been able to keep up (Burrell \& Nobles, 2018). 
Examining the status of cybersecurity education, it is evident that there are currently no definitive best practices (Burrell \& Nobles, 2018). The government and industry are trying to keep up internally by developing their own standards and training employees on systems that are continuing to change even as the training occurs (Burrell \& Nobles, 2018).

In 2013, the Computer Science Teachers Association (CSTA) published a report that includes data from the Bureau of Labor Statistics predicting that, by the year 2020, 50\% of all STEM related jobs will be in computing fields (Burrell \& Nobles, 2018). Their data shows that the growth rate of jobs in computing fields will exceed 150,000 per year over that period (Burrell \& Nobles, 2018). While Cybersecurity graduates will fill not all these positions, the need for more students entering all fields of computing, including Cybersecurity, is undeniable (Burrell \& Nobles, 2018). Meanwhile, computer science undergraduate enrollment numbers are still recovering from a rapid decline in enrollment that occurred between 2001 and 2007 (Burrell \& Nobles, 2018).

Given the difficulties in recruiting students into computer science departments discussed, departments should be doing everything within our power to provide high quality, engaging experience for those students who choose to enroll in our classes (Burrell \& Noble, 2018). One area where this is especially needed is cybersecurity (Burrell at el, 2015). Meeting the need to develop the cyber workforce also requires new processes and approaches to develop more effective teachers especially as new teachers enter the field (Fisher \& Burrell, 2011).

\section{COMPLEXITIES IN THE FIELD}

Due to this rapid growth, and the breadth of content areas that fall under the umbrella of cybersecurity, a wide array of curriculum and pedagogical practices are part of cybersecurity classrooms (Chisholm, 2015). While this diversity reflects the reality of cybersecurity education, it is a significant hindrance to the development of a comprehensive model for cybersecurity education which would allow for consistent and continuous improvement (Chisholm, 2015). For example, knowledge areas which could be incorporated into cybersecurity include: computer architecture, criminology/law, cryptography, databases, human-computer interaction, information retrieval, information theory, management/ business, mathematics, military science, mobile computing, networks, operating systems, digital forensics, philosophy/ethics, programming languages, software engineering, statistics/probability, and web programming (Burrell at el, 2015). Additionally, the expected outcomes from these courses may vary dramatically, with schools teaching cybersecurity as practical vocation skills, as good engineering practices, or as academic theories (Chisholm, 2015).

The pedagogical methods used to teach these courses are just as varied as the goals and content (Chisholm, 2015). Some courses focus on laboratory-based, experimental lessons. Others are lecturebased and involve the review and discussion of literature, and still others are challenge-based courses where instructors and students work together to solve problems (Chisholm, 2015). This wide array of content and approaches shows how challenging it is to determine what might constitute the best practices in cybersecurity education (Chisholm, 2015).

Adding to this problem is the fact that new technology and new vulnerabilities are thrown into the collective mix continuously, resulting in a continually changing body of knowledge that should be part of courses (Chisholm, 2015).

\section{NEW INSTRUCTORS}

Newly hired instructors face problems not covered during their academic studies (Sterrett \& Imig, 2011; Melnick \& Meister, 2008, \& Le Maistre \& Paré, 2010). Getting a degree, which includes practica, internships, and work-study programs, is not always enough to prepare instructors for the classroom experience (Le Maistre \& Paré, 2010). Newcomers to the university teaching profession often find challenges navigating the difference between textbook knowledge and practical knowledge. In this fast- 
changing world, the roles of teachers and expectancies placed upon them are continuously evolving, as they face the challenges of new skills, requirements, technological developments, individualized teaching, special learning needs, and increasing social and cultural diversity (Wen, 2014).

Beginning teachers are new teachers who have been teaching for three years (Melnick \& Meister, 2008). The most severe problem areas for these teachers are: motivating pupils, dealing with individual differences, assessing pupils' work, relations with parents, organization of classwork, insufficient materials and supplies, and dealing with problems of individual pupils (Merc, 2015). Lesser issues are relations with colleagues, planning of lessons; effective use of different teaching methods; awareness of school policies and rules; determining the learning level of students; knowledge of the subject matter, the burden of clerical work, and relations with principals/administrators (Merc, 2015). Teachers need to develop themselves in classroom management, in encountering students' varied needs, in distinguishing students' viewpoints (Merc, 2015).

New teachers need help with coping strategies because of a lack of classroom problem-solving strategies, which is gained through experience (Merc, 2015). Academic administrators must recognize the gap between veteran and new teachers so that assistance is provided to give them the tools to be effective at teaching (Merc, 2015). Mentoring, technology, collaborative leadership, and working within professional organizations are four areas to assist new teachers with gaining experience (Sterrett \& Imig, 2011).

Sterrett and Imig (2011) strongly support the mentoring of new teachers by either a veteran teacher or colleague in the areas of classroom management, alignment of curriculum, and managerial minutia. New teachers need either a mentor or veteran colleague to assist with the completion of forms, meeting deadlines, and protocols, which can be overwhelming (Fisher \& Burrell, 2011).

It is suggested that new teachers have the chance to shadow other highly skilled and experienced instructors (Fisher \& Burrell, 2011). Visiting colleagues will allow a new teacher to seek advice about pedagogy and work with students (Fisher \& Burrell, 2011).

\section{FACULTY DEVELOPMENT}

The University of Saskatchewan's study (2010) found beginning teachers found planning and collaboration with other teachers and professional development as the least need of support during their early years of classroom academic study (Prytula, Hellsten, \& McIntyre, 2010). The university examined two stages of teacher development, pre-service and in-service. Instructors can benefit through the collaboration and knowledge sharing that come from opportunities to get feedback and learn best practices (Fisher \& Burell, 2011). The method of collaboration and planning will enhance new instructors' learning and student-centered practices (Fisher \& Burrell, 2011).

At university and school levels, collaborative action research is vital for providing a diverse database for training materials, curricula, and theoretical discussions (Chisholm, 2015). Simulation and feedback offer a positive effect on beginning teachers, improving writing, mathematics, and problem-solving (Mitchell, Reilly, \&Logue, 2008). The development of a community of practice that focuses on collaborative action research enables the beginning teacher to participate in learning relationships (Fisher \& Burrell, 2011). New and creative methods of learning for beginning teachers are encouraged for learning must be continuous (Fisher \& Burrell, 2011). Attachment to old techniques does not always lead creativity around teaching and learning and often hinder the improvement process (Fisher \& Burrell, 2011).

\section{Employing the Lean Quality Improvement Approach for Improving Teaching}

Lean principles and practices, deep-rooted business management strategies, were introduced by the Japanese and launched explicitly by Taiichi Ohno (1912-1990). This lean production methodology pertains to all businesses and processes to include education (Jahan \& Doggett, 2015) in terms of adding value (Suárez-Barraza, Dahlgaard-Park, Rodríguez-González, \& Durán-Arechiga, 2016). 
Research regarding applying lean in education has been occurring for more than 18 years. Comm and Mathaisel (2005) gained data through a case study on the applicability of lean sustainability concepts to universities. This research team unturned the notion that higher education was focused mainly on cost reduction. Even though appropriate lean principles were not used, the universities were regularly effective in reducing waste, enhancing operational efficiency, and generally advancing sustainability (Comm \& Mathaisel, 2005). Later, Barroso, Santos, and Carravilla (2010) gave a report using numerous case studies on the manner that lean principles could be applied in higher education to improve processes. Later in, Hadzialic and Wiegel (2016) offered research on the application of lean methods in teaching, particularly in an undergraduate course. This research team focused on the use of Value Stream Mapping (VSM) to portray the teaching process, as well as insufficiencies of VSM for this purpose.

The concept of lean production continues to be a manner of thinking and acting to detect and eliminate waste, Muda (e.g., defects, overproduction, waiting, nonutilized talent, transportation, inventory, motion, and extra-processing; Suárez-Barraza, 2016). Two type of Muda exist, Muda type 1 and Muda type 2. Muda type 1 is necessary for end-customers, yet considered as non-valueadding (Dragulanescu, \& Popescu, 2015). For example, while an end-customer might not view quality inspection in educational materials as value-adding, such examination is necessary to ensure the academic materials meet academic standards to deliver accurate information. In other words, the correct data is essential for the performance of the educational activities that do add value. On the other hand, there is waste that adds no value and is unnecessary for end-customers, which is known as Muda type 2 (Dragulanescu, \& Popescu, 2015). Muda type 2 contributes to waste, incurs hidden costs, and should be eliminated and can be recalled through the acronym TIMWOOD (i.e., time, inventory, motion, waiting, overproduction, over-processing, and defects). Another acronym used, according to Smith (2015), is DOWNTIME (i. e., defects, overproduction, waiting, nonutilized workforce potential, transportation, inventory, motion, and excess processing). The driver, lead, and hidden source of type 2 Muda is mura (inconsistency, and irregularity; Khanh, \& Kim, 2015). Mura drives the waste of overburden, muri (Khanh, \& Kim, 2015). Next is muri, which is the overburdening of people and systems (Smith, 2014). Examples of muri include but are not limited to the following: attempting to work processes without training, ill-designed workplaces, vague instructions, inappropriate tools, and equipment, changing demand (Mura), absence of appropriate maintenance, undependable equipment, unpredictable/ inaccurate processes, in addition to mediocre communication channels. It is essential to understand that if Muri (overburden) and mura (imbalance) are corrected, considerable amounts of wastes (Muda) within the process will be eliminated because an overburdened person or system will more than likely produce waste (Smith, 2015). In addition to understanding waste in lean principles, it is crucial to comprehend the fundamental values of lean production.

The five fundamental values of lean production are specifying value, identify the value stream, smooth process flow, production based on the pull, and perfection through the elimination of waste (Sunder, 2013). Lean production methodology sought to maximize customer value while minimizing waste. Differing from widespread outlooks and comprehensive examination, the reason for lean approaches collect data, provide feedback, examining processes with a goal of improvement. The need is to focus on the big picture, accuracy, and not precision (Armstrong, \& Diehl, 2015), as one's thought to be precision could be inaccurate measures. Lean principles and methodologies support the enhancement of human capital by educating individuals to distinguish and rectify problems at their sources. Specific to higher education, lean can help to expand the value of higher education for learners, financiers, employees, and employers by using quality management approaches to improve instruction. This expansion of value includes brick and mortar, online education, and hybrid education. The types of educational institutions that can be affected include higher education, as well as K-12. Those who teach or train individuals can learn to apply lean principles by refining the quality of teaching (decreasing in errors), perfecting flow (purging waste, irregularity, and inconsistency), plus 
enriching the quality of learning (increasing retention, and correcting the application of information and processes). Numerous tools can be used to employ a lean quality improvement approach for improving teaching. For this article, ten quality tools fit to support the improvement of instruction.

\section{Tools and Usages}

\section{Brainstorming}

Brainstorming is a resourceful idea origination method which offers the opportunity to present individual ideas, without drawing criticism. Each concept is documented and thought to be a solution to a concern (Bullington, 2018).

\section{Check Sheet}

The check sheet is a fundamental tool of quality prevalent by Dr. Kaoru Ishikawa. The Check Sheet is utilized for assembling and analyzing information (ASQ, 2019a).

\section{Customer Requirements Matrix}

A tool to methodically gather and organize customers' requirement inputs. The Customer Requirements Matrix offers a lucid representation of how to meet the requirements and needs of the customer (Burton, 2016).

\section{Force Field Analysis}

A tool used to document information for and against a project. This tool can support stakeholders to decide concerns for meeting organizational goals (Duffy, Bauer, \& Moran, 2016).

\section{Gemba Process Walk}

This term is a process used to explain the personal observation of work and information learned. The Gemba walk is not to evaluate people performing the work (Kirkpatrick, 2015).

\section{Ishikawa Diagram (Fishbone Diagram)}

Ishikawa's cause-and-effect diagram, also known as a fishbone, helps decide the root causes of concerns in that solutions could arise (Popescu, Popescu, \& Popescu, 2014). The cause-and-effect diagram is employed in product design and quality defect prevention to detect the possible factors that are the foundation for a total effect.

\section{Plan Do Study Act}

Do, Study, Act (PDSA) cycles can be used to form parts of an enhancement guide, which provides a framework for planning, designing, developing, testing, and implementing changes leading to improvements. PDSA is an impactful tool for realizing data from workable ideas in addition to ideas that do not work (Hall, 2018).

\section{Process Map/ Process Flow Chart}

A graphical depiction of methodical steps for completing a procedure and is used to explain the procedure (ASQ, 2019b).

\section{SIPOC (Supplier, Input, Process, Output, and Customer)}

The SIPOC (supplier, input, process, output, \& customer) is a tool that recaps the inputs and outputs of one or more processes in table format (Fleacă, \& Jakubiak, 2018). These five (5) categories create the columns of the table. Typically, these elements are represented from left to right. 


\section{RACl (Responsible, Accountable, Informed, Consulted) Matrix}

The RACI matrix is used to define each team member's role (Troy \& Dewitte, 2014). It apprises individuals' workloads as it shows which role(s) are assigned to each person.

\section{Teaching Methods}

Another form of creative teaching is microteaching which is a proven and successful teaching technique (Fisher \& Burrell, 2011). The importance of this technique is to prepare beginning teachers for actual classroom teaching by strengthening their approach to teaching, identifying their strengths, assisting with developing empathic understanding of students as learners, enhancing the student teacher's teaching style, and improve the student teacher's ability to receive feedback (Satheesh, 2011, \& Gavrilović et al., 2011). Microteaching can be used at undergraduate, masters or professorship levels of education as well as for other areas of learning (Fisher \& Burrell, 2011). Student teachers are given 20 minutes to teach a lesson to their teacher and peers in a small group setting using flipcharts, overheads, and handouts (Fisher \& Burrell, 2011). Helpful tips for teaching are given as well as instructions for how to improve the way that students are engaged (Fisher \& Burrell, 2011). Useful feedback and questions for reflection are encouraged (Fisher \& Burrell, 2011).

The purpose of microteaching is to strengthen instructors teaching skills by helping them understand both their strengths and their weaknesses through simulated teaching experiences (Fisher $\&$ Burrell, 2011). The teaching cycle includes planning, teaching, feedback, re-planning, re-teaching, and re-feedback (Fisher \& Burrell, 2011). The rationale for the teaching procedure is based on behavior modification and an opportunity to gain constructive feedback on performance for improvement (Fisher \& Burrell, 2011).

According to Fisher and Burrell (2011), core teaching skills include probing questions, explaining, illustrating with examples, stimulus variation, reinforcement, classroom management, and using Blackboard:

- Teaching is a complicated process, but it can be analyzed into simple teaching tasks called teaching skills;

- Teaching skill is the set of behaviors/acts of the teacher which facilitates pupils' learning;

- Teaching is observable, definable, measurable, demonstrable and can be developed through training;

- Micro-teaching is a teacher training technique that plays a significant role in developing teaching skills among the new teachers;

- The procedure of micro-teaching involves the following steps: Plan $\rightarrow$ Teach $\rightarrow$ Feed-back $\rightarrow$ Replan $\rightarrow$ Re-teach $\rightarrow$ Re-feedback. These steps are repeated until the pupil-teacher attains mastery in the use of the skill;

- The micro-teaching cycle consists of all the stages of micro-teaching;

- For practicing teaching skill, the setting of micro-teaching involves:

- A single skill for practice;

- One concept of content for teaching;

- A class of 5 to 10 pupils;

- Time of exercies 5 to 10 minutes;

- Systematic use of feedback plays a significant role in the acquisition of the skill up to mastery level;

- After the acquisition of all the core skills, it is possible to integrate them for effective teaching in actual classroom-situations.

\section{Using Micro Teaching}

Microteaching has been successfully used in the United States and in other countries to assist teacher students in improving their skills (Napoles, 2008; Butler, 2001; Popovich, \& Katz, 2009; Mensa, et 
al., 2008; Mastromarino, 2004; \& Martin, \& Campbell, 1999). In the field of music, microteaching has been very useful for teacher effectiveness and performance using the microteaching technique (Butler, 2001; \& Napoles, 2008). Two studies are examined seven years apart in the field of music. The first study (Butler, 2001) involved 15 undergraduate students and evaluated teacher effectiveness using microteaching during two sessions. It was found the microteaching helped shaped the students' understanding of what it meant to teach. The second study, Napoles (2008), involved 36 instructors who taught three microteaching segments. Afterward, the instructions, peers, and students evaluated the parts. The instructors assessed themselves on areas they did well, suggestions for improvement, and effectiveness scores with ratings compared. A week later, the students were asked to recall their evaluations, an important aspect of the survey to see if students retained what they had learned from the sessions.

Teachers, educators, and all stakeholders in education must seek the best methods to help teachers understand, and continuously work on reform-oriented and technology-supported teaching and learning strategies (Fullan \& Langworthy, 2014). Teaching is a demanding and on-going profession. There are constant fluctuation and evolution, which requires improvement and enhancement. A portion of teaching is the ability to be able to adapt to various environments (Fisher \& Burrell, 2011). Therefore, it is evident that teaching evaluations could be a viable quality improvement process and a faculty development activity (Fisher \& Burrell, 2011). Teachers, like other professionals, should have a hungering need to update themselves, to engage in professional growth, to expand and deepen their understanding (Seldin, 1993).

Microteaching can be thought of as a quality management and instructional process improvement tool. The microteaching method offers different and new opportunities to pre-service teachers about planning and practicing a lot of theoretical knowledge, which they have learned throughout their undergraduate studies (Gürbüz, 2015, p. 2). The concept of micro-teaching encompasses the teacher being videotaped while teaching a lesson (Fisher \& Burrell, 2011). Once they have completed the lesson, the teacher is then evaluated and critiqued by other teachers as they watch the video (Fisher $\&$ Burrell, 2011). Micro-teaching is a cyclical process, comprised of the following phases: plan the activities, teach, criticize, re-plan, re-teach, and re-criticize (Fisher \& Burrell, 2011). The basic cyclical process includes numerous steps (Gocer, 2016). Following their lessons, students are afforded the opportunity to think about their teaching episodes and analyze both the positives that occurred and the areas on which they can improve (Diana, 2013). The development of micro teaching is to present to the teacher ways to improve their teaching in a real-life environment (Fisher \& Burrell, 2011). The goal is to give instructors confidence, support, and feedback by letting them practice a small part of what they plan to do with their students among friends and colleagues (Kusmawan, 2017). All educators know teaching in front of students is entirely different than any form of a practice lesson (Fisher \& Burrell, 2011).

Microteaching was incorporated in a professional development class (Popovich, \& Katz, 2009) and included communication skills, critical-thinking skills, and problem-solving abilities. The development of this class included a peer evaluation and a DVD of the student's presentation with a requirement to write a reflective essay of their performance. Microteaching is a valuable tool for assisting students with developing the skills of communication, critical-thinking, and problem-solving so students can think on their feet (Fisher \& Burrell, 2011). Their development is aided by classmates' input for students' personal development.

Microteaching is used in the field of therapy, (Mastromarino, 2004), to help convert theoretical knowledge into practical applications during interaction with patients. Five techniques were used: (1) role-playing and video or audio recording, (2) self-observational and/or supervision (monitoring), (3) reinforcement (dissonance), (4) re-experimentation, and (5) practice of the acquired abilities. It shows people improve their performance using this method of teaching.

The United Kingdom used micro-training for managing and participating in group discussions (Martin, \& Campbell, 1999). Recommendations were made by the Dearing Committee (1977) to 
develop student skills in universities and colleges around communicative abilities. It was believed that the development of the participant's ability to communicate during their teaching is a critical aspect of being a competent instructor (Fisher \& Burrell, 2011). The participants viewing themselves on video proved can be very helpful in developing their skills (Fisher \& Burrell, 2011).

\section{Development of New University Professors}

Microteaching is an excellent tool for preparing beginning teacher candidates for teaching at school to university professorship level (Fisher \& Burrell, 2011). It was a technique first developed in the early and mid-1960s at Sanford University to improve verbal and nonverbal areas of teacher's speech and general performance (Gavrilović et al., 2011). Dr. Dwight Allen and a group of his colleagues decided to improve student's teaching of science a model was developed that included teaching, with review and reflect, and re-teaching. (Gavrilović, et al., 2011). Later it was used to teach language, and from there, a similar model was developed, Instructional Skills Workshop (ISW), for college and institute faculty (Gavrilović, et al., 2011).

Since that time, the 1960s microteaching has been used in many schools, universities, and programs (Gavrilović et al., 2011). It has a strong background of success and has been used for five decades (Gavrilović et al., 2011). Microteaching is an excellent tool for developing new university professor and can be done through the creation of a required course that includes collaboration and journaling as well as an assigned mentor (Fisher \& Burrell, 2011). Videos should be done of the professor teaching and viewed with peers to focus on the elements of the lesson or teaching style (Fisher \& Burrell, 2011). Observations may include clarity of lesson explanation, voice and body language, and level of group interaction (Fisher \& Burrell, 2011). It is suggested that new university professors also are included in collaboration with veteran professors as well as assigned a mentor (Fisher \& Burrell, 2011). Even though microteaching can be given as a one-day event, it should be given as a longer course for new professors to assist with adjustment to academic activities (Fisher \& Burrell, 2011).

Novice teachers learn through the mentor capabilities of experienced teachers while reviewing the tapes (Fisher \& Burrell, 2011). The teachers can pause the video and provide feedback concerning a specific instruction of a lesson (Fisher \& Burrell, 2011). Teachers can learn about different teaching strategies by observing the way their peers teaching and find video recordings to be helpful for feedback and reflection (Bakir, 2014). The teacher can collect knowledge and make a note to adjust their teaching in the future (Fisher \& Burrell, 2011). It is a mirror for the teacher to view themselves, to improve upon themselves (Fisher \& Burrell, 2011). Teachers who have successfully incorporated professional development initiatives are able to see how these successful initiatives impact their teaching (Stair, Warner, Hock \& Conrad, 2016). Microteaching appears to have the potential to introduce best practices as well as instilling critical thinking, which may emerge when contradictions are experiences (Davids, 2016).

Microteaching is a way to adjust the quality and approach of how teachers teach (Fisher \& Burell, 2011). It is a tool for all teachers, novice ones, to be able to view themselves teaching and incorporate feedback from experienced teachers and mentors to fine-tune their abilities in an age when faculty evaluations are completed without any intervention to improve instruction. Witterholt, Goedhart, and Suhre (2016) have emphasized that teachers learn through reflection on their teaching practices. Microteaching allows teachers to experience teaching in a controlled setting.

The process of microteaching also provides the teachers the feedback from their peers, as a means of critiquing teaching behaviors and techniques (Fisher \& Burrell, 2011). The process allows instructors to engage in reflection and inquiry on the theory and practice of their teaching (Fisher \& Burrell, 2011). Exchanging knowledge and experiences triggers reflection on each other's teaching practices and ideas, which may in turn result in an expansion of teacher knowledge and the refinement of one's teaching practices (Witterholt, Goedhart, \& Suhre, 2016). During a microteaching exercise, the students can notice strong and weak points about their teaching skills 
(Bakir, 2014). Results confirm that this kind of training does make a significant and lasting impact on teaching (Gibbs \& Coffey, 2004).

Although micro-teaching can offer numerous benefits, it can also be utilized as a form of teacher collaboration (Fisher \& Burrell, 2011). The significance of teacher collaboration has been highly emphasized in the field of teacher education over the past decades (Yuan \&Zhang, 2016). Teacher collaboration can stimulate educational innovation and professional learning $(\mathrm{Xu}, 2015)$. Teachers working together can provide instances of best practices, classroom management, teaching styles, and curriculum assignments (Fisher \& Burrell, 2011).

Microteaching offers numerous opportunities for learning and reflective action; most respond positively in terms of the guidance and advice that they receive (Davids, 2016). Teacher collaboration can assist teachers with their teaching practices to improve their lessons and teaching materials (Kafyulilo, 2013). The use of collaboration provides learning and support for the teachers (Chiouhui, 2011). Collaboration is vital to the progress of teachers within a functioning institution. While the teachers are reviewing their tapes, it is a time for them to converse with one another and discuss the concepts within the videos (Fisher \& Burrell, 2011). Teachers working together can provide interaction focusing on the teaching within the videos. Bowser, Davis, Singleton, \& Small (2017) suggested that learning that focuses on collaboration increases the ability for improvement through a combination of the knowledge, experiences, and expertise of multiple participants.

\section{CONCLUSION}

With more universities offering specialized computer science degrees with an emphasis on security, finding qualified instructors is difficult (Burrell \& Nobles, 2018). According to Stevenson (2017), an instructor's ability to create and deliver relevant course experiences is a critical job requirement in producing a well-versed security technologist. The goal is to produce cybersecurity program graduates with comparable industry skills (Burrell, at el., 2015).

Translating tactical skills into practical ones, for Cybersecurity students is becoming an essential aspect of the computer security curriculum (Burrell, at el., 2015). Having teachers that can effectively help students develop critical cybersecurity skills is a vital aspect of workforce training and development (Burrell at el., 2015). Microteaching provides a tool for developing cybersecurity professionals that are critical to the development of a skilled cybersecurity workforce. 


\section{REFERENCES}

American Society of Quality [ASQ]. (2019a). Check sheet. Retrieved from https://asq.org/quality-resources/ check-sheet

American Society of Quality [ASQ]. (2019b). What is a process flow chart? Retrieved from https://asq.org/ quality-resources/flowchart

Armstrong, A. J., \& Diehl, G. W. (2015). Lean needs both pictures. Industrial Engineering (American Institute of Industrial Engineers), 47(10), 26-30. Retrieved from https://proxy.cecybrary.com/login?url=https://searchproquest-com.proxy.cecybrary.com/docview/1720975837?accountid=144459

Aubry, L. (2011, March 17). Bad teachers are rarely fired. Why? Los Angeles Sentinel, 11, A7, 1.

Blake, S. (2008). "A nation at risk" and the blind men. Phi Delta Kappan, 89(8), 601-602.

Burton, S. L. (2016). Lean: Understanding a customer requirements matrix. Retrieved from https://www. slideshare.net/SharonLBurtonABDHCS/lean-understanding-a-customer-requirements-matrix-2016

Butler, A. (2001). Preservice music teachers' conceptions of teaching effectiveness microteaching experiences, and teaching performance. Journal of Research in Music Education, 49(3), 258-272.

Barroso, I. P. M., Santos, S. M. F., \& Carravilla, M. A. (2010). Beyond classroom boundaries: How higher education institutions apply lean. The 1st Brazilian Symposium on Services Science, Nov, 17-19, 2010, Brasilia, Brazil.

Bullington, K. (2018). Sticking out the storm. Quality Progress, 51(9), 24-32. Retrieved from https://proxy. cecybrary.com/login?url=https://search-proquest-com.proxy.cecybrary.com/docview/2131176310?account $\mathrm{id}=144459$

Burrell, D., Finch, A., Simmons, J., \& Burton, S. (2015). The Innovation and Promise of STEM-Oriented Cybersecurity Charter Schools in Urban Minority Communities in the United States as a Tool to Create a Critical Business Workforce. In M. Dawson \& M. Omar (Eds.), New Threats and Countermeasures in Digital Crime and Cyber Terrorism.

Burrell, D., \& Nobles, C. (2018). Recommendations to Develop and Hire More Highly Qualified Women and Minorities Cybersecurity Professionals. The Proceedings of the International Conference on Cyber Warfare and Security. Academic Conferences International Limited.

Carter, L. (2006). Why students with an apparent aptitude for computer science don't choose to major in computer science. ACM SIGCSE Bulletin, 38(1), 27-31.

Cheung, R., Cohen, J., Lo, H., \& Elia, F. (2011). Challenge based learning in cybersecurity education. In Proceedings of the 2011 International Conference on Security \& Management, volume 1.

Chisholm, J. A. (2015). Analysis on the perceived usefulness of hands-on virtual labs in cybersecurity classes (Order No. 3717270). Available from ProQuest Dissertations \& Theses Global. (1711732271).

Clement, M. C. (2010) Preparing teachers for classroom management: The teacher educator's role. The Delta Kappa Gamma Bulletin, Fall, 41-44.

Comm, C. L., \& Mathaisel, D. F. X. (2005). A case study in applying lean sustainability concepts to universities. International Journal of Sustainability in Higher Education, 6(2), 134-156.

Dragulanescu, I., \& Popescu, D. (2015). Quality and competitiveness: A lean six sigma approach. Amfiteatru Economic, 17(9), 1167-1182. Retrieved from https://proxy.cecybrary.com/login?url=https://search-proquestcom.proxy.cecybrary.com/docview/1732759158?accountid=144459

Duffy, G. L., Buarer, J., \& Moran, J. W. (2016). Solve problems with open communication. Quality Progess, 49(1), 33 .

Fisher, J., \& Burrell, D. (2011). The value of using micro teaching as a tool to develop instructors. Review of Higher Education and Self-Learning, 3(11), 86-94. 
Fleacă, B., \& Jakubiak, M. (2018). Modeling processes to meet organisational objectives. FAIMA Business \& Management Journal, 6(2), 57-65. Retrieved from https://proxy.cecybrary.com/login?url=https://search-proquestcom.proxy.cecybrary.com/docview/2078623789?accountid=144459

Gainsburg, J. (2009). Creating effective video to promote student-centered teaching. Teacher Education Quarterly, (Spring): 163-178.

Gavriliović, T. Ostojić, M., Sambunjak, D., Kirschfink, M., Steiner, T., and Stritmatter, V. (n.d.) Chapter 5: Microteaching. Retrieved May 4, 2011 from http://www.bhmed-emanual.org/book/export/html/36

Hadzialic, L. B., \& Wiegel, V. (2016). Case study: Using value stream mapping in the educational process how focusing on student actions can help depict the teaching process. International Journal of Six Sigma and Competitive Advantage, 10(1), 50-61. https://doi.org/10.1504/IJSSCA.2016.080451

Hall, L. L. (2018). Quality improvement using Plan-Do-Study-Act. American Medical Association (AMA). Retrieved from https://www.stepsforward.org/modules/pdsa-qualityimprovement

Jahan, M., \& Doggett, A. M. (2015). A study on the students' perceptions of the applicability of lean principles. American Society for Engineering Education. 122nd ASEE Annual Conference \& Exposition. June 14-17, 2015 Seattle, Washington. (Paper ID\# 12977).

Khanh, H. D., \& Kim, S. Y. (2015). Development of waste occurrence level indicator in Vietnam construction industry. Engineering, Construction, and Architectural Management, 22(6), 715-731. Retrieved from https:// proxy.cecybrary.com/login?url=https://search-proquest-com.proxy.cecybrary.com/docview/1732318154?acco untid $=144459$

Kirkpatrick, B. (2015). What comes after a gemba walk? Industry Week, Retrieved from https://proxy.cecybrary. com/login?url=https://search-proquest-com.proxy.cecybrary.com/docview/1692244641 ?accountid=144459

Le Maistre, C., \& Paré, A. (2010). Whatever it takes: How beginning teachers learn to survive. Teaching and Teacher Education, 26(3), 559-564.

Martin, D., \& Campbell, B. (1999). Managing and participating in group discussion: A micro-training approach to the communication skill development of students in higher education. Teaching in Higher Education, 4(3), 327-337.

Mastromarino, R. (2004). The use of microteaching in learning the redecision model: A proposal for an observation grid. Transactional Analysis Journal, 34(1), 37-47.

Melnick, S. A., \& Meister, D. G. (2008). A comparison of beginning and experienced teachers' concerns. Educational Research Quarterly, 31(3), 39-56.

Mensa, K. O., Ahiatrogah, P. D., \& Deku, P. (2008). Challenges facing female distance learners of the University of Cape Coast, Ghana. Gender \& Behaviour, 6(2), 1751-1764.

Mitchell, S. N., Reilly, R. C., \& Logue, M. E. (2009). Benefits of collaborative action research for the beginning teacher. Teaching and Teacher Education, 25(2), 344-349.

Napoles, J. (2008). Relationships among instructor, peer, and self-evaluations of undergraduate music education majors' micro-teaching experiences. Journal of Research in Music Education, 56(1), 82-91.

Popovich, N. G., \& Katz, N. L. (2009). Instructional design and assessment. A microteaching exercise to develop performance-based abilities in pharmacy students. American Journal of Pharmaceutical Education, 73(4), 1-8.

Popescu, C. R., Popescu, G. N., \& Popescu, V. A. (2014). Japanese miracle versus thirty-six years of excellence in American searching groping. Manager, (19), 18-26. Retrieved from https://proxy.cecybrary.com/login?url=https:// search-proquestcom.proxy.cecybrary.com/docview/1619354221 ?accountid=144459

Prytula, M. P., Hellsten, L. M., \& McIntyre, L. J. (2010). Perception of teacher planning time: And epistemological challenge. Current Issues in Education, 14(1), 4-29. Retrieved from http://cie.asu.edu/ojs/index.php/cieatasu/ article/view/437

Satheesh, K. (2008, November 15). Introduction to micro-teaching [Web log post]. Retrieved from http://sathitech. blogspot.com/2008/11/introction-to-micro-teaching.html 
Smith, S. (2014). Muda, muri and mura. ASQ Six Sigma Forum Magazine, 13(2), 36-37. Retrieved from https:// proxy.cecybrary.com/login?url=https://search-proquest-com.proxy.cecybrary.com/docview/1505315316?acco untid $=144459$

Sterrett, W. L., \& Imig, S. (2011). Thriving as a new teacher in a bad economy. Kappa Delta Pi Record, 47(2), 68-71.

Stevenson, G. V. (2017). Cybersecurity implications for industry, academia, and parents: A qualitative case study in NSF STEM education (Order No. 10624075). Available from ProQuest Dissertations \& Theses Global. (1958945736).

Suárez-Barraza, M. F., Dahlgaard-Park, S., Rodríguez-González, F. G., \& Durán-Arechiga, C. (2016). In search of "Muda" through the TKJ diagram. International Journal of Quality and Service Sciences, 8(3), 377-394. doi:http://dx.doi.org.proxy.cecybrary.com/10.1108/IJQSS-04-2016-0028

Sunder, V. M. (2013). Synergies of lean six sigma. IUP Journal of Operations Management, 12(1), 21-31.

Troy, B., \& Dewitte, P. (2014). Social media texting merges with RACI to enhance project management. World Oil, Retrieved from https://proxy.cecybrary.com/login?url=https://search-proquest-com.proxy.cecybrary.com/ docview/1685870223? accountid $=144459$

Wilson, M. (2010). There are a lot of really bad teaches out there. Phi Delta Kappan, 92(2), 51-55. 